UDC 657

DOI: https://doi.org/10.30839/2072-7941.2019.165136

\title{
FINANCIAL STATEMENTS FORMATION IN THE CONTEXT OF THE MANAGEMENT PARADIGM
}

\author{
(C) BIRUTE், PETROŠIENE \\ Marijampole college, Lithuania \\ E-mail bir.petr@mkolegija.lt; ORCID: 0000-0002-5160-8249 \\ C JOLITA, URKIENE \\ Marijampole college Lithuania, \\ E-mail: jol.urk@mkolegija.lt \\ (C) DANGUOLE், ŠIDLAUSKIENE \\ Marijampole college, Lithuania \\ E-mail: dan.sidl@ mkolegija.lt, ORCID: 000-0002-9154-2934
}

\begin{abstract}
Financial statements are the main source of information showing the performance of an enterprise and its financial state. They are need for business management, analysis, internal and external audit, owners and state, investors, society. The set of financial statements is prepared by summarizing the company's financial year data. To prepare accountability, data is pre-accumulated and grouped in accounting records, synthetic and analytical accounting registers according to general principles: continuity, periodicity, permanence, prudence, monetary measure, accumulation, neutrality, relevance of content, importance of information (the most important ones, and necessary to know). These accounting principles are followed in the EU countries. According to A. Ivanauskiene, an annual stocktaking must be carried out before the annual financial statements are drawn up [3]. Accounting policy part includes accounting principles and a brief description of accounting methods and rules that are used by the entity in accounting and financial reporting. [2]. Accounting policies are general accounting principles, accounting methods, and rules intended for accounting management, formation and submission of financial accountability" the definition is provided by A. Ivanauskiene [3]. For more information on accounting policies is written $6 \mathrm{BAS}$ - the explanatory note of the accounting policy part should state that 'financial statements are prepared in accordance with business accounting standards. Other legal acts that have been used for accounting management and financial reporting purposes [1] are also included. At the end of the company's financial year, we have to prepare not only financial statements, but also to analyze it properly. Because only by submitting an annual analysis of financial statements we will be able to evaluate the company's performance and position. We will be able to determine whether the company's performance is profitable, whether by putting together and discussing all the reports, there is a risk for the company's future plans. Problem and Relevance - it is very important that the financial accountability reports would be prepared correctly and would perform their intended purpose. Accurate accumulation and systematization of accounting information allows to account correctly assets, capital, income and expenses. Otherwise, false information will result in distorted analysis results and its users will make wrong decisions. The aim of the work is to analyze the content of financial statements, principles of formation and use of data.Research object - financial accountability.Research objectives: 1. To analyze the essence and importance of financial accountability, to provide a systematic description of financial
\end{abstract}

(C) Birutė Petrošiene \& Jolita Urkiene \& Danguolė Šidlauskiene, 2019 
accountability. 2. To provide a procedure for regulating accountability and how to allocate it. 3. To set requirements for financial reporting. 4. To prove the importance of financial reporting with respect to companies.Research methods - analysis of scientific literature, including the comparison of theoretical statements, methods of generalization, logical and graphical representation. Conclusions: Financial statements should reflect fair information about the financial position and performance of the entity, as well as provide necessary information to internal and external users and disclose relevant information about significant events occurring during the reporting period. Preparation of financial statements is regulated by: Law on Accounting of the Republic of Lithuania, Law on Financial Accountability of the Republic of Lithuania, Consolidated Financial Accountability Compilation of the Republic of Lithuania, International Business Accounting Standards, National Business Accounting Standards, Accounting Policies shaped in the company. The data presented in the annual financial statements shall be prepared in accordance with the general accounting principles. The information received in the reports must be compared to the previous reporting periods and to the performance of other companies. The data obtained are needed for economic analysis, audit, planning of the company performance and forecasting.

Keywords: accounting policies, set of financial statements, accounting principles.

The problem is presented in general terms and its connection with important scientific or practical tasks. Relevance of research topic. Financial statements are the main source of information showing the performance of an enterprise and its financial state. They are need for business management, analysis, internal and external audit, owners and state, investors, society. The set of financial statements is prepared by summarizing the company's financial year data. To prepare accountability, data is preaccumulated and grouped in accounting records, synthetic and analytical accounting registers according to general principles: continuity, periodicity, permanence, prudence, monetary measure, accumulation, neutrality, relevance of content, importance of information (the most important ones, and necessary to know). These accounting principles are followed in EU countries. According to A. Ivanauskiené, an annual inventory must be made before the annual financial statements are drawn up [3]. The first Business Standard 'Financial Accountability' in its General Provisions states the following:

1) The objective of financial accountability is to specify the procedures for the preparation of the annual financial statements and the requirements for comparing the financial statements with the financial statements of previous periods of the same entity and the financial statements of other entities;

2) The standard is applied to the preparation and presentation of annual financial accountability in accordance with Business Accounting Standards;

3) This Standard establishes the procedures for financial accountability presentation, composition and general requirements for the content of statements. The preparation of financial statements, the recognition of economic operations and events, evaluation and disclosure while analyzing other business accounting standards [1]. Also, A. Ivanauskienè writes that when filling in financial statements it is necessary to take into 
account qualitative characteristics of financial statements related to the value of information to consumers. Key features are highlighted by the BAS and International Accounting Standards (IAS). Financial statement information should be: clear; understandable; appropriate; reliable; detail; delivered on time; comparable; complied with the requirements of the BAS, legislation and company accounting policy requirements [1]. The first Business Standard 'Financial Accountability' distinguishes the following key concepts:

Explanatory note - part of the annual financial accountability that explains the amounts reported in the balance sheet, profit (loss), cash flow and changes in equity reports, as well as discloses additional significant information that is not presented in the financial statements. The explanatory note includes information required by Business Accounting Standards, as well as other information, that is required to present fairly the financial position, performance and cash flows of a company.

Accounting policies are general accounting policies, accounting methods and rules for accounting management of a company and preparation and presentation of financial reporting.

Reporting period - the period for which the financial statements are prepared.

Balance sheet is a financial statement that shows all the assets, equity and liabilities of the enterprise at the last day of the reporting period.
A company is a profit-making entity.

The annual financial statements are the financial statements prepared by summarizing the financial data of the company for the financial year.

Statement of Changes in Equity - a financial statement that provides information about changes in equity during the reporting period.

Income is an increase in economic benefits that results from an increase in the asset (or its value) over the reporting period or a decrease in liabilities that increases equity, excluding additional contributions from owners.

Cash Flow is a financial statement that identifies income and payment of cash and cash equivalents over the reporting period of a company [1].

Thus, financial reporting is the most important source of information in a company's performance. Only by knowing and understanding all the concepts of financial reporting it is possible to carry out successfully one's business plans. Because the essence of this reporting is to bring every action of the company (e.g. money movement) into the required reports, and only then having evaluated all the reports it is possible to argue whether the company is on the right track.

Problem and Relevance - it is very important that the financial accountability reports would be prepared correctly and would perform their intended purpose. Accurate accumulation and systematization of accounting information allows to account correctly assets, capital, income and expenses. Otherwise, 
false information will result in distorted analysis results and its users will make wrong decisions. The aim of the work is to analyze the content of financial statements, principles of formation and use of data. Research object - financial accountability. Research objectives:

1. To analyze the essence and importance of financial accountability, to provide a systematic description of financial accountability;

2. To provide a procedure for regulating accountability and how to allocate it;

3. To set requirements for financial reporting.

4. To prove the importance of financial reporting with respect to companies.

Research methods - analysis of scientific literature, including the comparison of theoretical statements, methods of generalization, logical and graphical representation.

Undoubtedly, only accounting based on the principles of data collection and income and cost comparison can provide accurate information on the assets, ownership and success of their business. As with any complex phenomenon, accountability can be described in the most detailed way by discussing its classification, in which these accounts are grouped according to various attributes. However, it should not be forgotten that this classification, like every other classification, has some limitations. Our life, as well as the performance of companies, is very diverse with many nuances, so sometimes it is very difficult to draw a strict boundary between the assignment of a reporting form to one or another classification group. The new edition of Law on Accounting sets out four categories of companies (Article 4 of the Law): very small, small, medium and large enterprises [9]. Different composition of financial statements sets is determined for different categories of companies.

The financial statements set of small companies consists of a balance sheet or a condensed balance sheet, profit (loss) statement and explanatory note. Very small companies may not prepare explanatory notes, and then their financial statements consist of a condensed balance sheet and a short income (loss) statement. As in the past, the financial statements of medium and large companies consist of five financial statements. The requirements of the condensed balance sheet, short balance sheet, short income (loss) statement are set by Business Accounting Standards if the financial statements are prepared in accordance with business accounting standards [1]. In terms of content and periodicity, accountability can be divided into annual, quarterly, monthly, weekly or decadent, as well as non-periodic, compiled according to requirement. By classifying accountability by periodicity, it is grouped not only by time, but also by content. Thus, the annual accountability covers the entire company performance during the reporting financial year. But the most important is the form of quarterly reporting. This is because companies have to pay taxes to the state at the end of each quarter. In terms of scope, reporting is divided into full and 
abbreviated. Some stock companies are very large, others, especially the joined ones, can be quite small, with little impact on the national economy, and their owners have invested a small asset in such companies. As a result, they are allowed to prepare annual financial statements based on the principle of data collection, but somewhat shortened.Even the balance sheets and profit (loss) statements, as well as other forms, differ among the companies preparing the shortened reporting. Some reports are not mandatory for small businesses in general.

Foreign authors also write about financial reporting standards. Jill Colls states that ,accounting standards provide preparers of financial statements with an authoritative guide to the most appropriate method for accounting for many of the important activities undertaken by companies. They apply to all entities that prepare financial statements intended to provide a true and fair view. Accounting standards provide users of financial statements with more information than is required by legislation alone. Users also have information about the basis on which the financial statements have been drawn up, which aids comparison with previous years and with other companies" [5].

The accountability classification is important and useful, because having compiled and grouped it well, the accounts of one or the next year can be found and compared easily and quickly. To this end, we can see if our company is thriving, there are additional charges, etc.
Financial reporting information and its users. accounting is a means of transferring information about an enterprise's economic activity to those interested in the company's performance. accounting provides information that underpins economic decisions by all those engaged in economic activity. accounting information has become a landmark in investing capital and calculating the return on capital already invested. it is one of the most effective elements of economic work, which actively affects not only the economy of a particular company, but also the economy of the whole republic.

Accounting plays a unifying role. Having the opportunity to invest in companies of different businesses, sizes and even countries, both investors and accountants who produce accounting data need to be able to communicate. Therefore, accounting information, provided to external users, must be based on uniform rules. Every manager knows that company performance can be reflected in different results, which depend on accounting and reporting techniques. As a result, international accounting standards (IAS), the European Union (EU) directives in the European Union and general accounting principles (GAPs) in each country are internationally regulated in order to harmonize accounting rules as much as possible [7].

Accounting reflects every economic transaction, data on economic facts are recorded, grouped and summarized in such a way that information indicators on the company's assets, funds, sources of 
their formation, results of the company performance, financial status would be formed. Economic transactions include the purchase of goods and other assets - sales, giving loans and crediting, provision and receipt of services. Accounting provides information about the use of material, labor, financial resources in the company and provides this information to the management of the company as well as employees of its units. Accounting helps the user at any time to get information about the company's:

- debts owed to the company;

- creditor debts (company debts to third parties);

- profit (loss) of the reporting periods;

- sources of profit or loss formation;

- the size and composition of the ownership of the owners;

- scope and composition of liabilities [8].

General accounting principles. The general accounting principles (GAPs) are of great importance for the accounting system, especially for regulating financial accounting. These are the most important generally accepted accounting rules and statements that keep track of accounting across the civilized world.

The general accounting principles are provisions that underpin the conceptual accounting rules of each free market country. Their importance could be compared to a person's ability to speak to others in an intelligible language. If we only create a language that we understand, we will not be able to communicate to others. The same is also applied to accounting: if we do not follow universally accepted principles, no one understands the financial information formed - says A. Ivanauskienè [3].

The Law on the Financial Accountability of Enterprises of the Republic of Lithuania contains the following general accounting principles: company's business continuity; periodicity; stability; monetary measure; accumulation; comparison; caution; neutrality; importance of content the listed principles are followed by accounting staff of all fields (manufacturing, construction, agriculture, trade, etc.). They are applied to all countries of market economies, in most companies, regardless of their operating conditions. These principles have been developed in defining and implementing the most important financial reporting requirements [3].

The general principles are formulated in International Accounting Standards, European Union Directives on Accounting and Preparation of Financial Accounting, as well as in similar national regulations and other accounting literature. Although these principles are sometimes treated in a slightly different way in the above mentioned regulatory acts, they do, in principle, declare the same standards for financial accounting and reporting [4].

Having analyzed the general principles, it can be said that each principle is closely related. It is necessary to draw the essence of each principle in the financial statements, as only then our financial statements 
will be prepared properly and will comply with the accounting standards.

Financial statements. Financial statements are formal documents that show the financial position and performance of an enterprise or other organization. They are prepared by accountants or accounting clerk. The purpose of financial reporting is to meet the needs of information users by obtaining information about the company's financial position, performance and cash flows. Usually, companies and other organizations only prepare financial statements mandatory by law. First, the companies themselves assess which group of companies they belong to. Then, under BAS 1, 'Financial Statements', reports are provided. This allocation is needed to avoid imposing excessive burdens on businesses and additional unnecessary administrative work. The financial statements make it possible to compare the financial situation of very small and small enterprises. The statements include the reporting period and the previous reporting period [1]. The financial statements must be accurate and correct. According to the BAS and Aldona Ivanauskiene, a different composition of financial statements (FS) has been established for different company categories [3].

A very small company's FS set consists of: short balance + additional information; short profit (loss) statement. A small company's FS Set includes: balance sheet or condensed balance sheet; profit (loss) statement; explanatory note Explanatory note is a free-form document in which companies want to further clarify one or another balance sheet item or provide information that is not recorded in other financial statements. Medium and large company's FS set includes: balance sheet; profit (loss) statement; cash flow statement; statement of changes in equity; Explanatory note. Medium and large company's FS must be filled by public interest entities and stateowned, municipality-owned enterprises.

Financial reporting analysis. Companies that want to minimize risk and avoid many troubles have to analyze their activities. Financial analysis provides perhaps the most useful economic information that can be used to make more accurate decisions. Financial accounting requires comprehensive accounting knowledge. No legislation or normative documents provide for financial analysis. Currently, many business executives underestimate the importance of financial analysis. With market relations, competitive struggles among companies, the importance of financial analysis will increase due to the following key issues:

- Financial analysis helps to reveal internal reserves and make rational economic decisions.

- There are practically no areas of production, commerce, services or other activities that would not allow and should not use certain elements of financial analysis;

- The manager of each company is interested in the opportunities of the company and its prospects for development. 
Financial analysis provides systematic information to anticipate operational strategy and future prospects. In the analysis, financial statements are used: balance sheet, profit (loss) statement, statement of changes in equity, cash flow statement. Each financial statement provides information about the company in another aspect. Financial analysis indicators are more accurate and more reliable after the audit of financial statements, argues A. Ivanauskienè [3].

At the end of the company's financial year, we have to prepare not only financial statements, but also to analyze it properly. Because only by submitting an annual analysis of financial statements we will be able to assess the company's performance and position. We will be able to determine whether the company's activities are profitable, whether by putting together and discussing all the reports, there is a risk for the company's future plans.

\section{Conclusions:}

1. Financial statements should reflect fair information about the financial position and performance of the company, as well as provide necessary information to internal and external users and disclose relevant information about significant events occurring during the reporting period.

2. The preparation of financial statements is regulated by: Law on Accounting of the Republic of Lithuania, Law on Financial Accountability of the Republic of Lithuania, Consolidated Financial
Statements of the Republic of Lithuania, International Business Accounting Standards, National Business Accounting Standards, Accounting Policies in the company.

3 . The data presented in the annual financial statements must be prepared in accordance with the general accounting principles.

4. In completing the financial reporting forms, it is necessary to comply with the qualitative reporting requirements. All valuation techniques are defined in BAS 1 Financial Statements.

5. The balance sheet describes the entity's total assets and equity and liabilities, and shows the assets that the entity owns and manages.

6. Profit (loss) statement shows income earned, expenses incurred and economical result - profit (loss).

7. The statement of changes in equity shows information on changes in equity during the reporting period.

8. The cash flow statement shows how and for what reasons a significant asset type has changed in the entity cash.

9. In the above-mentioned reports, the company discloses information in the explanatory notes.

10. The manager is responsible for preparing the annual report.

11. The information received in the reports can be compared with the previous reporting periods and with the performance of other companies. The data obtained are needed for economic analysis, audit, planning of the company and forecasting. 


\section{REFERENCES}

1. Audito apskaitos tarnyba, Verslo apskaitos standartai (2015). Vilnius.

2. Bagdžiūnienè, V. (2015). Apskaitos politika. Vilnius.

3. Ivanauskienè, A. (2016). Buhalterinè apskaita. Vilnius: Tytoalba.

4. Kalčinskas, G., Kalčinskaitė, R. (2017). Buhalterinè apskaita. Vilnius.

5. Collis, J. (2015). Financial Accounting. Palgrave MacMillan.

6. Stačiokas, R. (2016). Apskaitos organizavimo ir sąskaitybos pagrindai. Kaunas.

7. Balanso turtas. Available at:

http://verslokelias.eu/resursu_katalogas/content/learning_material/I_II_pakopu_studentams/2 91533.html

8. Lietuvos Buhalterinès apskaitos įstatymas NR. IX-574 (2001). Vilnius.

9. Gabrevičienè, A., Petrošienė, B., Šidlauskienè, D. (2018). Internal audit and control in a company in the context of management activity. Humanities Bulletin of Zaporizhzhe State Engineering Academy, 74, 190-198. doi: https://doi.org/10.30839/2072-7941.2018.149678

ПЯТРОШЕНЕ, БІРУТЕ - лектор, Маріямпольська колегія (Маріямполь, Литва)

E-mail: bir.petr@mkolegija.lt, ORCID: 0000-0002-5160-8249

УРКЕНЕ, ЙОЛІТА - студентка програми «Бухгалтерський облік», Маріямпольська колегія (Маріямполь, Литва)

E-mail: jol.urki@mkolegija.lt

ШИДЛАУСКЕНЕ, ДАНГОУЛЕ - лектор, Маріямпольська колегія (Маріямполь, Литва)

E-mail: dan.sidl@ mkolegija.lt, ORCID ID: 000-0002-9154-2934

\section{СКЛАДАННЯ ФІНАНСОВОГО ЗВІТУ У КОНТЕКСТІ УПРАВЛІНСЬКОЇ ПАРАДИГМИ}

Анотація. Финансові звіти є основним джерелом інформації, що свідчать про результати діяльності підприємства та його фінансовий стан. Вони необхідні для управління, аналізу, внутрішнього i зовнішнього аудиту, власникам i державі, інвесторам, суспільству. Комплект фінансової звітності складається шляхом узагальнення даних фінансового року компанії. Дані для звітності попередньо накопичуються і групуються в облікових записах, синтетичних та аналітичних облікових регістрах у відповідності з загальними принципами: безперервність, періодичність, незмінність, обережність, грошові показники, накопичення, нейтральність, релевантність змісту i значимість інформації. Ці принципи бухгалтерського обліку дотримуються у країнах ЄС. Стаття базується на основі аналізу Стандартів обліку підприємництва, закону бухгалтерського обліку та досліджень Bagdžiūniene (2015), Ivanauskiene (2016), Kalčinskas, Kalčinskaite (2017), Stačiokas, R., Jefimovas (2016) та ін. У кінці фінансового року компанії потрібно не тільки підготувати фінансову звітність, але й правильно іiі проаналізувати. Щорчний аналіз фінансової звітності дає можливість правильно оцінити результати підприємства, визначити, чи прибутовою $є$ його діяльність, чи існує ризик при складанні і обговоренні всіх звітів на майбутнє. Актуальним є те, щоб фінансова звітність була підготовлена правильно i за призначенням. Точна облікова інформація дозволяе правильно враховувати активи, капітал, прибутки і розходи. У противному випадку інформація приведе до викривлення результатів аналізу і до неправильних рішень користувачів. Постановка цілі - вивчити зміст фінансової звітності, принципи іiі складання та використання даих. У статті для досягнення цілі означені завдання - проаналізувати (C) Birutė Petrošiene \& Jolita Urkiene \& Danguolè Šidlauskiene, 2019 
сутність і значення фінансової звітності, дати систематичний опис фінансової звітності; представити правила регулювання бухгалтерського обліку i способи його розповсюдження; встановити вимоги до фінансової звітності і визначити важливість фінансової звітності для підприємств. Методи роботи - аналіз і синтез наукової літератури, порівняння. Висновки. Фінансова звітність повинна відображати достовірну інформацію про фінансовий стан і результати діяльності підприємства, а також надати відповідну інформацію внутрішнім і зовнішнім користувачам і розкрити відповідну інформацію про визначні події, що відбулися на протязі звітного періоду; підготовка фінансової звітності, що регулюється Законом про фінансовий облік Лтовської Респубілки, Законом про фінансову звітність Литовської Респубілки, Консолідованою фінансовою звітністю Литовської Респубілки, Міжнародними стандартами бухгалтерського обліку, Національними стандартами бухгалтерсього обліку, Обліковою політикою. Інформація, отримана у звітах, повинна порівнюватися 3 попередніми звітаними періодами і з результатами інших підприємств. Отримані дані необхідні для економічного аналізу, аудиту, планування і прогнозування діяльності підприємства.

Ключові слова: Облікова політика, комплект фінансової звітності, принципи бухгалтерського обліку.

ПЯТРОШЕНЕ, БИРУТЕ - лектор, Мариямпольская коллегия (Марияполь, Литва) E-mail: bir.petr@mkolegija.lt; ORCID ID: 0000-0002-5160-8249

УРКЕНЕ, ЙОЛИТА - студентка программы «Бугалтерский учет», Мариямпольская коллегия (Мариямполь, Литва)

E-mail: jol.urki@mkolegija.lt

ШИДЛАУСКЕНЕ, ДАНГОУЛЕ, - лектор, Мариямпольская коллегия (Марияполь, Литва)

E-mail: dan.sidl@mkolegija.lt, ORCID ID: 000-0002-9154-2934

\section{СОСТАВЛЕНИЕ ФИНАНСОВОГО ОТЧЕТА В КОНТЕКСТЕ УПРАВЛЕНЧЕСКОЙ ПАРАДИГМЫ}

Аннотация. Финансовые отчеты являются основным источником информации, показывающим результаты деятельности предприятия и его финансовое положение. Они требуются для управления, анализа, внутреннего и внешнего аудита, собственникам и государству, инвесторам, обществу. Комплект финансовой отчетности составляется путем обобщения данных финансового года компании. Данные для отчетности предварительно накапливаются и группируются в учетных записях, синтетических и аналитических учетных регистрах в соответствии с общими принципами: непрерывность, периодичность, постоянство, осторожность, денежные показатели, накопление, нейтральность, релевантность содержания и значимость информации. Эти принципы бухгалтерского учета соблюдаются в странах ЕС. Анализ последних иссследовниий и публикаций. Статья основанна на анализе Стандартов учета предпринимательста, закона бухгалтерского учета и исследований Bagdžiūniene (2015), Ivanauskiene (2016), Kalčinskas, Kalčinskaite (2017), Stačiokas, R., Jefimovas (2016) и др. В конце финансового года компании нужно не только подготовить финансовую отчетность, но и правильно ее проанализировать. Ежегодный анализ финансовой отчетности дает возможность правильно оценить результаты предприятия, определить, прибыльна ли деятельность, существует ли риск при составлении и обсуждении всех отчетов на будущее. Актуално, чтобы финансовая отчетность была подготовлена правильно и по назначению. Точная учетная информация позволяет

Financial statements formation in the context of the management paradigm 
правильно учитывать активы, капитал, доходы и расходы. В противном случае информация приведет к искажению результатов анализа и к неправильным решениям пользователей. Постановка цели - изучить содержание финансовой отчетности, принципы составления и использования данных В статье для достижения цели намечены задачи - проанализировать сущность и значение финансовой отчетности, дать систематическое описание финансовой отчетности; представить правила регулирования бухгалтерского учета и способы его распространения; установить требования к финансовой отчетности и определить важность финансовой отчетности для предприятий. Методы работы - анализ и синтез научной литературы, сравнение. Выводы. Финансовая отчетность должна отражать достоверную информацию о финансовом положении и результатах деятельности предприятия, а также предоставлять соответствующую информацию внутренним и внешним пользователям и раскрывать соответствующую информацию о значительных событиях, произошедших в течение отчетного периода; подготовка финансовой отчетности регулируется Законом о бухгалтерском учете Литовской Республики, Законом о финансовой отчетности Литовской Республики, Консолидированной финансовой отчетностью Литовской Республики, Международными стандартами бухгалтерского учета, Национальными стандартами бухгалтерского учета, Учетной политикой. Информация, полученная в отчетах, должна сравниваться с предыдущими отчетными периодами и с результатами других предприятий. Полученные данные необходимы для экономического анализа, аудита, планирования и прогнозирования деятельности предпрмятияю

Ключевые слова: Учетная политика, комплект финансовой отчетности, принципы бухгалтерского учета.

Стаття рекомендована до публікаиіï Andriukaitiene, Regina - Doctor $\mathrm{PhD}$ of social sciences, Associate Professor (Мариямполь, Литва) Надійшла до редколегіï: 09.02.2019 p. Прийнята до друку: 19.02.2019 p. 